\title{
Effect of Cr Addition on Glass-Forming Ability and Corrosion Properties of FeCoSiBPC Bulk Glassy Alloys
}

\author{
Xue $\mathrm{Li}^{1, *}$, Yu Liu ${ }^{1}$, Dechuan $\mathrm{Yu}^{1}$, Xining $\mathrm{Li}^{1}$, Dongying $\mathrm{Ju}^{1}$ and Akihiro Makino ${ }^{2}$ \\ ${ }^{1}$ School of Material and Metallurgy, University of Science and Technology Liaoning, \\ 185 Qianshan Zhong Road, Anshan, Liaoning, 114051, P. R. China \\ ${ }^{2}$ Institute for Materials Research, Tohoku University, Sendai 980-8577, Japan
}

The FeCoSiBPCCr bulk glassy alloys (BGAs) were prepared by micro-alloying technique. The glass forming ability (GFA) and softmagnetic properties of the BGAs were examined by X-ray diffraction, TEM, DSC and VSM. The corrosion resistance of the alloys was evaluated by electrochemical measurements and the mechanical properties were tested by macro-compression experiments. The results show that the GFA and corrosion resistance of the FeCoSiBPCCr BGAs are significantly improved with increasing $\mathrm{Cr}$ content while the mechanical and magnetic properties exhibit no obvious change. The $\mathrm{Fe}_{64.4} \mathrm{Co}_{7.6} \mathrm{Si}_{7} \mathrm{~B}_{10} \mathrm{P}_{5} \mathrm{C}_{2} \mathrm{Cr}_{2} \mathrm{BGA}$ rods with diameters up to $5 \mathrm{~mm}$ were produced by copper mold casting. These BGAs exhibit excellent corrosion resistance as well as high saturation magnetization of $1.3 \mathrm{~T}$, low coercive force of $3.1 \mathrm{~A} / \mathrm{m}$ and high fracture strength of more than $3700 \mathrm{MPa}$. [doi:10.2320/matertrans.M2018062]

(Received February 16, 2018; Accepted May 2, 2018; Published July 25, 2018)

Keywords: iron-based glass alloy, glass-forming ability, corrosion resistance, magnetic property

\section{Introduction}

In industrial applications, electromagnetic component of the electronic equipment is frequently used under the harsh conditions such as damp, acidic and other corrosive environments. For example, electromagnetic equipments are used in marine environment for flaw detection systems ${ }^{1)}$ or seafloor resources and tectonics. ${ }^{2)}$ In addition, the transformers used in chemical industries are much easily corroded. These electromagnetic parts should possess good anticorrosive resistance to corrosive conditions as well as specific soft-magnetic properties and high mechanical properties. It has been reported that a layer of compact and uniform passivation layer can be formed on the surface in $\mathrm{Fe}-$ $\mathrm{Cr}$ alloys by introducing $\mathrm{Cr}$, which improves the corrosion resistances of the alloys. ${ }^{3)}$ Moreover, some studies show that the amount of $\mathrm{Cr}$ addition should be not less than 12 mass $\%$ to obtain good corrosion resistance in $\mathrm{Fe}-\mathrm{Cr}$ alloys., ${ }^{4,5}$ However, the excessive $\mathrm{Cr}$ addition will inevitably cause the decrease of magnetic properties as well as soil and water pollutions. On the other hand, with the miniaturization trend of electronic devices, the standards for excellent magnetic material become more and more high. At present, the application of corrosion resistant soft magnetic alloy is greatly limited; hence it is urgent to develop new corrosion resistant soft magnetic materials.

Since the ferromagnetic Fe-C-P glassy alloy ribbons were prepared by Duwez, ${ }^{6}$ Fe-based soft magnetic glassy alloys have attracted a lot of attention. So far Fe-based bulk glassy alloys (BGAs) have been widely used in various transformers, inductors and sensors and become an indispensable basic material in electricity, electronics and information fields. ${ }^{7-12)}$ However, the glass forming abilities (GFAs) of the Fe-based BGAs are rather low. The Fe-based BGAs only can be obtained at the cooling rate of more than $\left.10^{6} \mathrm{~K} / \mathrm{s},{ }^{13}\right)$ which greatly restrict the development of $\mathrm{Fe}$ based magnetic glassy materials with complicated shapes.

*Corresponding author, E-mail: xli@ustl.edu.cn
In addition, the GFA and corrosion resistance of Fe-based glassy alloys largely depend on the components. ${ }^{14-20)} \mathrm{A}$ large amounts of non ferromagnetic elements are usually added to Fe-based BGAs in order to improve the corrosion resistance, which lead to the decrease and even disappear of magnetic properties at room temperature. ${ }^{21-23)}$ Therefore, it is necessary to develop Fe-based BGAs with good corrosion resistance and high magnetic properties.

FeSiBP bulk glassy alloys were developed by Makino et al. in 2007. ${ }^{24)}$ These Fe-based BGAs without any other metal elements exhibit high saturation magnetization and GFA. Recently, Wang et al. increased the GFA as well as saturation induction density $\left(B_{s}\right)$ by adding a little amount of carbon in FeSiBP alloys. ${ }^{25)}$ The FeSiBPC alloys exhibit high $B_{s}$ of 1.61-1.68 T and ribbons with critical thickness of $81 \mu \mathrm{m}$ can be made by single roller melt-spun method. Zhao et al. further investigated the effect of $\mathrm{Co}$ on $\mathrm{FeCoSiBPC}$ alloys. ${ }^{26)}$ With Co addition, $B_{s}$ increases to $1.74 \mathrm{~T}$ while soft magnetic properties deteriorate. In this study, we aim at developing the amorphous alloys with good corrosion resistance as well as GFA and magnetic properties. Based on good glass-forming abilities and magnetic properties of FeCoSiBPC BGAs, the effect of $\mathrm{Cr}$ element on the corrosion resistance, glassforming abilities and magnetic properties of $\mathrm{FeCoSiBPCCr}$ alloys will be discussed.

\section{Experimental Procedure}

$\mathrm{Fe}_{68.4-x} \mathrm{Co}_{7.6} \mathrm{Si}_{7} \mathrm{~B}_{10} \mathrm{P}_{5} \mathrm{C}_{2} \mathrm{Cr}_{x} \quad(x=0,1,2,3)$ alloy ingots were prepared by induction melting under a high purified argon atmosphere using the elements with high purity of Fe (99.99 mass\%), Co (99.99 mass\%), Cr (99.9 mass\%), Si (99.99 mass\%), B (99.9 mass\%) and C (99.99 mass\%) and the prealloyed ingot of $\mathrm{Fe}_{3} \mathrm{P}$ (99.5 mass \%). Their compositions are nominally expressed in atomic percentage. The glassy alloy ribbons with a cross section of $0.02 \mathrm{~mm}$ were prepared by single-roller quenching. Cylindrical rods with diameters $3.5-5.0 \mathrm{~mm}$ and length of $40 \mathrm{~mm}$ were fabricated by copper mold casting under a high purified argon atmosphere. 
The samples were annealed at the temperature below glass transition temperature $\left(T_{g}\right) 20-50 \mathrm{~K}$ for 5-20 min.

The structure of the sample was examined by X-ray diffraction (XRD) with $\mathrm{Cu}-\mathrm{K} \alpha$ radiation. The thermal stability associated with Curie temperature $\left(T_{c}\right)$, glass transition temperature $\left(T_{g}\right)$, crystallization temperature $\left(T_{x}\right)$, supercooled liquid region $\left(\Delta T_{x}=T_{x}-T_{g}\right)$ was examined by a differential scanning calorimetry (DSC) at a heating rate of $0.067 \mathrm{~K} / \mathrm{s} .{ }^{18)}$ The melting $\left(T_{m}\right)$ and liquidus $\left(T_{l}\right)$ temperatures were measured with a differential thermal analyzer (DTA) at a heating rate of $0.067 \mathrm{~K} / \mathrm{s} .{ }^{18)}$ Magnetic properties, saturation induction density $\left(B_{s}\right)$ and coercive force $\left(H_{c}\right)$ were measured with a vibrating sample magnetometer and a B-H loop tracer. Compressive deformation tests were performed on instron testing machine at a strain rate of $5 \times 10^{-4}$ at room temperature using glassy rods with a dimension of $1.5 \mathrm{~mm}$ in diameter and $4 \mathrm{~mm}$ in length. Corrosion properties of the samples were evaluated by electrochemical measurements in $1 \mathrm{~N} \mathrm{H}_{2} \mathrm{SO}_{4}$ solution at room temperature. Prior to electrochemical measurements, the specimens were mechanically polished with $\mathrm{SiC}$ paper up to grit 1500 , cleaned using an ultrasonic cleaner and then dried in air for $24 \mathrm{~h}$. Electrochemical measurements were conducted in a threeelectrode cell using a platinum counter electrode and $\mathrm{Ag} / \mathrm{AgCl}$ reference electrode. Potentiodynamic polarization curves were measured at a potential sweep rate of $50 \mathrm{mV} / \mathrm{min}$ after open-circuit immersion for about $20 \mathrm{~min}$.

\section{Results and Discussion}

The Fe-based BGAs were designed as $\mathrm{Fe}_{68.4-x} \mathrm{Co}_{7.6^{-}}$ $\mathrm{Si}_{7} \mathrm{~B}_{10} \mathrm{P}_{5} \mathrm{C}_{2} \mathrm{Cr}_{x}(x=0,1,2$ and 3$)$. Since the magnetic properties deteriorate with decreasing $\mathrm{Fe}$ content, the $\mathrm{Cr}$ content not more than 3 at\% was selected in this study to improve the corrosion resistance.

\subsection{Structural analysis}

The $\mathrm{Fe}_{68.4-x} \mathrm{Co}_{7.6} \mathrm{Si}_{7} \mathrm{~B}_{10} \mathrm{P}_{5} \mathrm{C}_{2} \mathrm{Cr}_{x}(x=0,1,2$ and 3$)$ BGA rods were prepared by $\mathrm{Cu}$-mold casting. The glassy structures were confirmed by XRD patterns for the cross sections of the samples, as shown in Fig. 1. All of the XRD patterns reveal a broad peak around $2 \theta=44.6^{\circ}$, which is the characteristic of the amorphous structure. No other detectable crystalline peaks can be identified within the detection limit of the XRD measurement. This indicates that all the alloys examined in this study are mostly amorphous. The results show that the critical diameter for the formation of a single glassy phase is $3.5 \mathrm{~mm}$ for $x=0$ and $1,5.0 \mathrm{~mm}$ for $x=2$, and $4.0 \mathrm{~mm}$ for $x=3$. The variation tendency of the critical diameter is consonant with the predicted results according to DSC and DTA data.

\subsection{GFA}

DSC curves for the ribbon samples of the $\mathrm{Fe}_{68.4-x} \mathrm{Co}_{7.6^{-}}$ $\mathrm{Si}_{7} \mathrm{~B}_{10} \mathrm{P}_{5} \mathrm{C}_{2} \mathrm{Cr}_{x}(x=0,1,2$ and 3$)$ glassy alloy are shown in Fig. 2. Each DSC trace exhibits a distinct glass transition, followed by a super-cooled liquid region. The results are summarized in Table 1. It can be found that the glass transition temperature $\left(T_{g}\right)$ decreases from $786 \mathrm{~K}$ to $771 \mathrm{~K}$ with increasing $\mathrm{Cr}$ content. The crystallization temperature

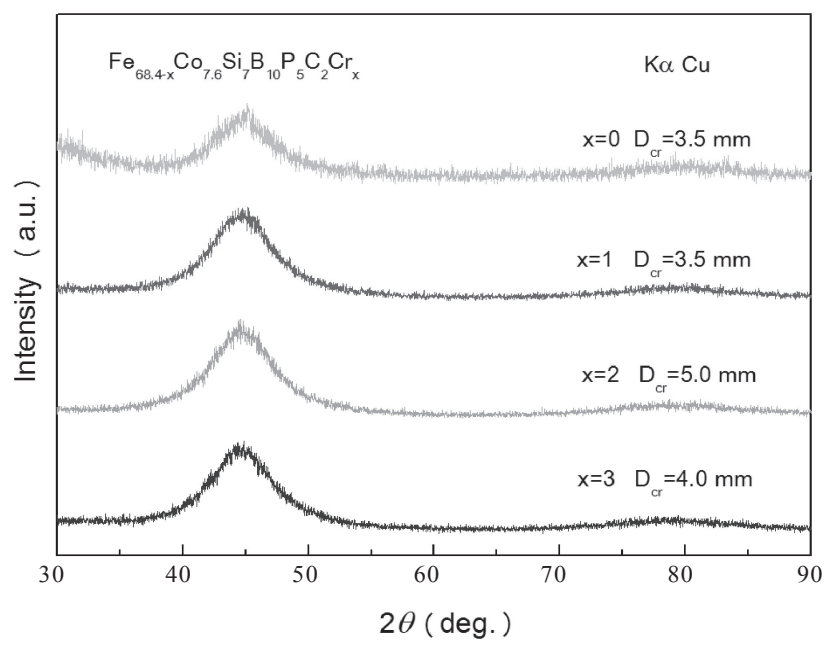

Fig. 1 XRD patterns of $\mathrm{Fe}_{68.4-x} \mathrm{Co}_{7.6} \mathrm{Si}_{7} \mathrm{~B}_{10} \mathrm{P}_{5} \mathrm{C}_{2} \mathrm{Cr}_{x}(x=0 \sim 3)$ glassy alloy rods.

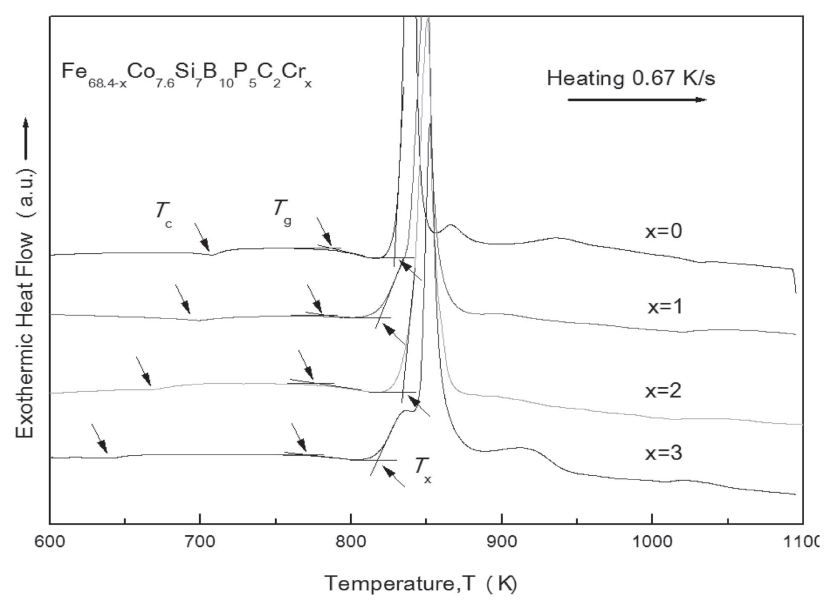

Fig. 2 DSC curves for the ribbon samples of $\mathrm{Fe}_{68.4-x} \mathrm{Co}_{7.6} \mathrm{Si}_{7} \mathrm{~B}_{10} \mathrm{P}_{5} \mathrm{C}_{2} \mathrm{Cr}_{x}$ $(x=0 \sim 3)$ glassy alloy.

$\left(T_{x}\right)$ and $\Delta T_{x}$ decrease from $830 \mathrm{~K}$ to $821 \mathrm{~K}$ and $44 \mathrm{~K}$ to $40 \mathrm{~K}$ with the addition of $1 \mathrm{at} \% \mathrm{Cr}$ element. When $2 \mathrm{at} \% \mathrm{Cr}$ is continually added to the alloy, the $T_{x}$ and $\Delta T_{x}$ conversely increase to $835 \mathrm{~K}$ and $59 \mathrm{~K}$, respectively. Further addition of $\mathrm{Cr}$ to 3 at $\%$, the $T_{x}$ and $\Delta T_{x}$ decrease to $817 \mathrm{~K}$ and $45 \mathrm{~K}$. Although there is only one exothermic peak in the curves of both the alloys for $x=1$ and 2, the shapes of the two peaks are different. The slope of the curve for $x=1$ alloy significantly deflects on the left side, but the $x=2$ alloy shows a smooth curve in both sides of the endothermic peak. With the amount of $\mathrm{Cr}$ added up to 3 at\% $(x=3)$, two endothermic peaks appear in the curve. These results indicate that the composition of $x=2$ alloy lies in the vicinity of a eutectic point and has the widest interval of the supercooled liquid region $\left(\Delta T_{x}=59 \mathrm{~K}\right)$. It implies that this alloy has a large glass-forming energy. The Curie temperature $T_{c}$ decreases with alloying $\mathrm{Cr}$ element to the glassy alloys, and the lowest $T_{c}$ value is $645 \mathrm{~K}$ in the composition of $x=3$ alloy. These results imply that a minor addition of Cr element $(x \leq 2)$ has no obvious influence on the stability of the ferromagnetism. The alloy system still maintains strong ferromagnetism at a high temperature. 
Table 1 Thermal property, glass forming ability, critical diameter and magnetic property of $\mathrm{Fe}_{68.4-x} \mathrm{Co}_{7.6} \mathrm{Si}_{7} \mathrm{~B}_{10} \mathrm{P}_{5} \mathrm{C}_{2} \mathrm{Cr}_{x}(x=0 \sim 3) \mathrm{BGAs}$.

\begin{tabular}{lccccccccc}
\hline \multicolumn{1}{c}{ Composition } & $T_{\mathrm{c}}(\mathrm{k})$ & $T_{\mathrm{g}}(\mathrm{k})$ & $T_{\mathrm{x}}(\mathrm{k})$ & $T_{\mathrm{m}}(\mathrm{k})$ & $\Delta T_{\mathrm{c}}(\mathrm{k})$ & $T_{\mathrm{rg}}$ & $D(\mathrm{~mm})$ & $B_{\mathrm{s}}(\mathrm{T})$ & $H_{\mathrm{c}}(\mathrm{A} / \mathrm{m})$ \\
\hline $\mathrm{Fe}_{68.4} \mathrm{Co}_{7.6} \mathrm{Si}_{7} \mathrm{~B}_{10} \mathrm{P}_{5} \mathrm{C}_{2}$ & 707 & 786 & 830 & 1279 & 44 & 0.6145 & 3.5 & 1.38 & 2.3 \\
$\mathrm{Fe}_{67.4} \mathrm{Co}_{7.6} \mathrm{Si}_{7} \mathrm{~B}_{10} \mathrm{P}_{5} \mathrm{C}_{2} \mathrm{Cr}_{1}$ & 700 & 781 & 821 & 1270 & 40 & 0.6149 & 3.5 & 1.35 & 2.7 \\
$\mathrm{Fe}_{66.4} \mathrm{Co}_{7.6} \mathrm{Si}_{7} \mathrm{~B}_{10} \mathrm{P}_{5} \mathrm{C}_{2} \mathrm{Cr}_{2}$ & 670 & 776 & 835 & 1259 & 59 & 0.6164 & 5 & 1.30 & 3.1 \\
$\mathrm{Fe}_{65.4} \mathrm{Co}_{7.6} \mathrm{Si}_{7} \mathrm{~B}_{10} \mathrm{P}_{5} \mathrm{C}_{2} \mathrm{Cr}_{3}$ & 645 & 771 & 817 & 1252 & 46 & 0.6158 & 4 & 1.21 & 3.0 \\
\hline
\end{tabular}

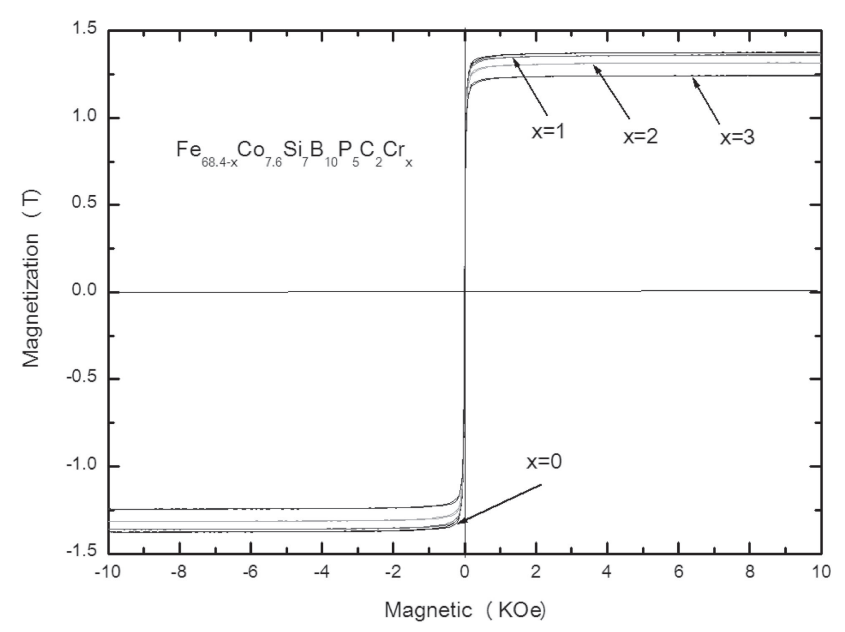

Fig. 3 Hysteresis loops of $\mathrm{Fe}_{68.4-x} \mathrm{Co}_{7.6} \mathrm{Si}_{7} \mathrm{~B}_{10} \mathrm{P}_{5} \mathrm{C}_{2} \mathrm{Cr}_{x}(x=0 \sim 3)$ glassy alloy rods with a diameter of $2 \mathrm{~mm}$.

The $T_{m}$ and $T_{r g}\left(T_{r g}=T_{g} / T_{m}\right)$ of $\mathrm{Fe}_{68.4-x} \mathrm{Co}_{7.6} \mathrm{Si}_{7} \mathrm{~B}_{10^{-}}$ $\mathrm{P}_{5} \mathrm{C}_{2} \mathrm{Cr}_{x}(x=0,1,2$ and 3$)$ glassy alloy were measured by DTA and the results are summarized in Table 1 . The $T_{r g}$ value increases with the addition of $2 \% \mathrm{Cr}$ element and then slightly decreases with further increasing $\mathrm{Cr}$ content to $3 \%$. The maximum value of the $T_{r g}$ is 0.6164 for $x=2$ alloy. The $T_{r g}$ is related to the viscosity. The larger the $T_{r g}$ value is, the greater the effect of temperature on the viscosity of the supercooled liquid is. As the temperature decreases, the viscosity rapidly increases and the resistance of the atom diffusion increases, that is benefit to improve the glassforming energy.

\subsection{Magnetic properties}

Figure 3 shows VSM traces of $\mathrm{Fe}_{68.4-x} \mathrm{Co}_{7.6} \mathrm{Si}_{7} \mathrm{~B}_{10} \mathrm{P}_{5} \mathrm{C}_{2} \mathrm{Cr}_{x}$ $(x=0,1,2$ and 3$)$ glassy alloys. The saturation magnetization $\left(J_{s}\right)$ decreases from $1.38 \mathrm{~T}$ for the alloy without $\mathrm{Cr}$ to $1.21 \mathrm{~T}$ for the alloy with 3 at\% $\mathrm{Cr}$ addition. The ribbon samples with similar composition subjected to annealing for $300 \mathrm{~s}$ at a temperature of $50 \mathrm{~K}$ under $T_{g}$ have the $H_{c}$ of 2.3$3.1 \mathrm{~A} / \mathrm{m}$. These results show that this alloy system behaves a rather good magnetic property.

\subsection{Mechanical properties}

Figure 4 shows compressive stress-strain curves of $\mathrm{Fe}_{68.4-x} \mathrm{Co}_{7.6} \mathrm{Si}_{7} \mathrm{~B}_{10} \mathrm{P}_{5} \mathrm{C}_{2} \mathrm{Cr}_{x}(x=0,1,2$ and 3$)$ BGA rods

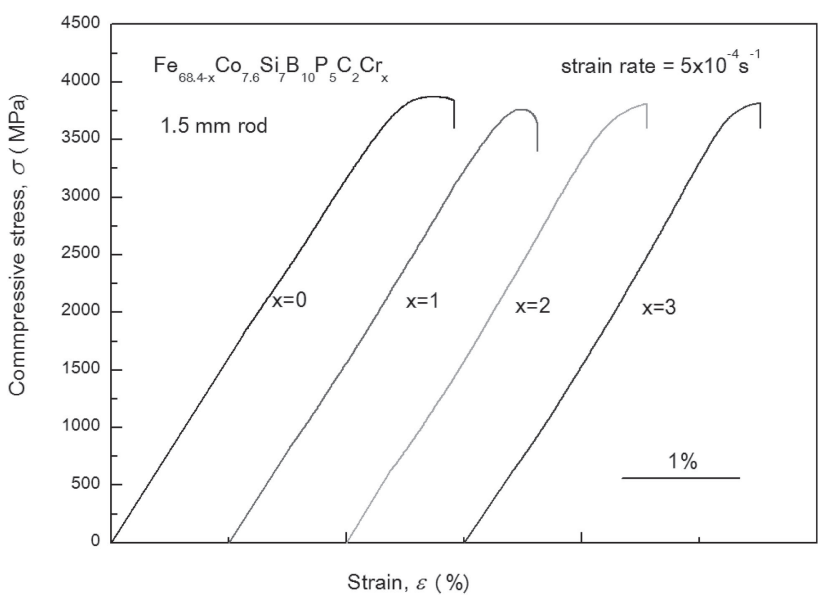

Fig. 4 Compressive true stress-strain curves of cast $\mathrm{Fe}_{68.4-x} \mathrm{Co}_{7.6^{-}}$ $\mathrm{Si}_{7} \mathrm{~B}_{10} \mathrm{P}_{5} \mathrm{C}_{2} \mathrm{Cr}_{x}(x=0 \sim 3)$ glassy alloy rods with a diameter of $1.5 \mathrm{~mm}$.

with a diameter of $1.5 \mathrm{~mm}$. The curve without $\mathrm{Cr}$ behaves like a typical Fe-based glassy alloy, exhibiting an elastic strain of about $2 \%$ at yield strength of $3700 \mathrm{MPa}$, Young's modulus of $190 \mathrm{GPa}$ and plastic strain of about $0.3 \%$. Compared with the alloy without $\mathrm{Cr}$, both the plastic strains and the fracture strengths decrease with $\mathrm{Cr}$ addition. In Cr-added alloys, the fracture strength slightly increases to $3800 \mathrm{MPa}$ with increasing $\mathrm{Cr}$ content and the fracture strength of $\mathrm{Fe}_{65.4} \mathrm{Co}_{7.6} \mathrm{Si}_{7} \mathrm{~B}_{10} \mathrm{P}_{5} \mathrm{C}_{2} \mathrm{Cr}_{3}$ is very close to that of the alloy without $\mathrm{Cr}$. The specimen was broken into several small pieces after compression test due to the high fracture strength and the poor plasticity. Figure 5 shows the fracture surface morphology of one broken pieces (a) and shear bands on the specimen surface (b). Several shear bands near the fracture plane were observed, but the number of shear bands is small. There is not enough shear band to be one of the reasons for the poor plasticity of the $\mathrm{Fe}_{68.4-x} \mathrm{Co}_{7.6} \mathrm{Si}_{7} \mathrm{~B}_{10^{-}}$ $\mathrm{P}_{5} \mathrm{C}_{2} \mathrm{Cr}_{x}(x=0,1,2$ and 3$) \mathrm{BGA}$ rods as the activation of the shear bands is benefit to the compressive plasticity.

\subsection{Corrosion resistance}

The corrosion resistance tests of $\mathrm{Fe}_{68.4-x} \mathrm{Co}_{7.6} \mathrm{Si}_{7} \mathrm{~B}_{10} \mathrm{P}_{5^{-}}$ $\mathrm{C}_{2} \mathrm{Cr}_{x}(x=0,1,2$ and 3$)$ were conducted by electrochemical measurements. Figure 6 shows the potentiodynamic polarization curves of $\mathrm{Fe}_{68.4-x} \mathrm{Co}_{7.6} \mathrm{Si}_{7} \mathrm{~B}_{10} \mathrm{P}_{5} \mathrm{C}_{2} \mathrm{Cr}_{x}(x=0 \sim 3) \mathrm{BGA}$ rods with a diameter of $2 \mathrm{~mm}$ in $1 \mathrm{~N} \mathrm{H}_{2} \mathrm{SO}_{4}$ solution open to 

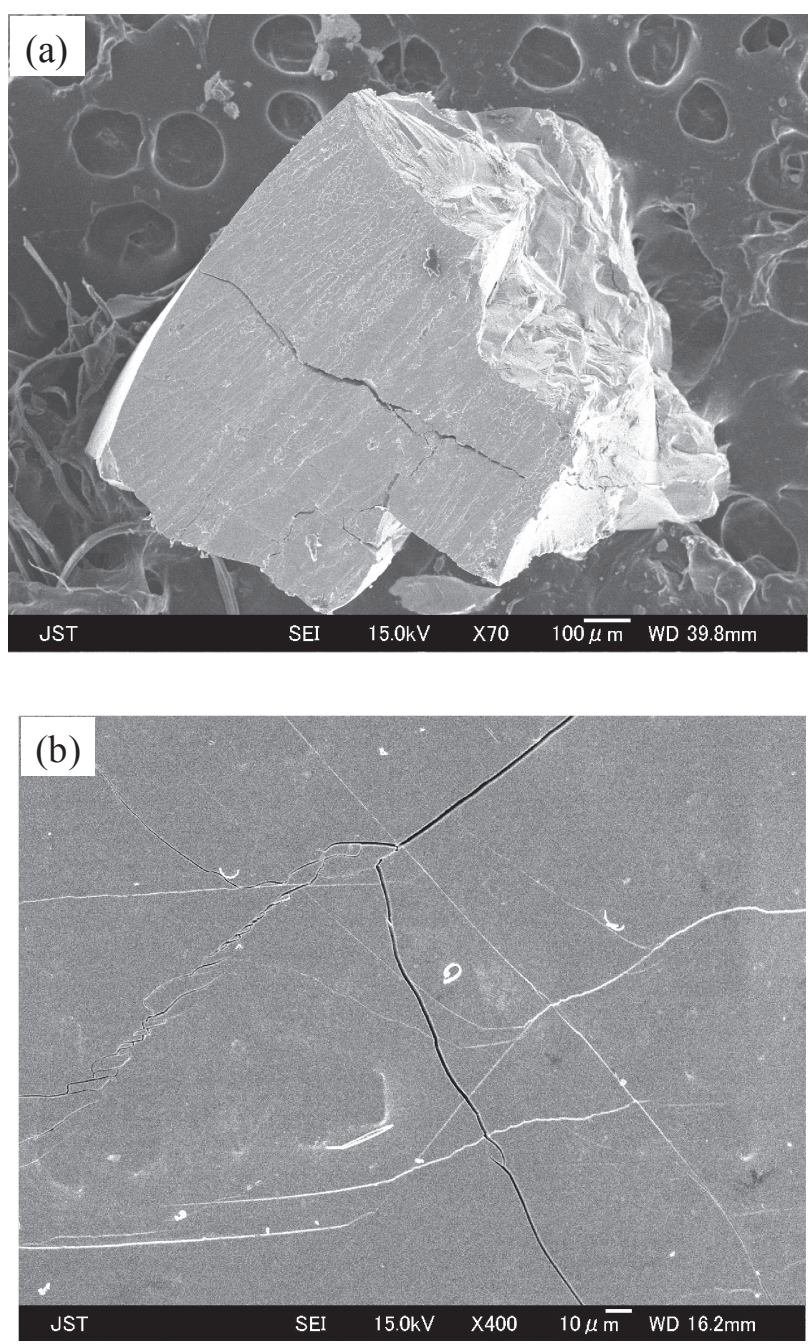

Fig. 5 Fracture surface morphology (a) and shear bands on the specimen surface (b) of the $\mathrm{Fe}_{68.4-x} \mathrm{Co}_{7.6} \mathrm{Si}_{7} \mathrm{~B}_{10} \mathrm{P}_{5} \mathrm{C}_{2} \mathrm{Cr}_{x}(x=2)$ glassy alloy rods with a diameter of $1.5 \mathrm{~mm}$.

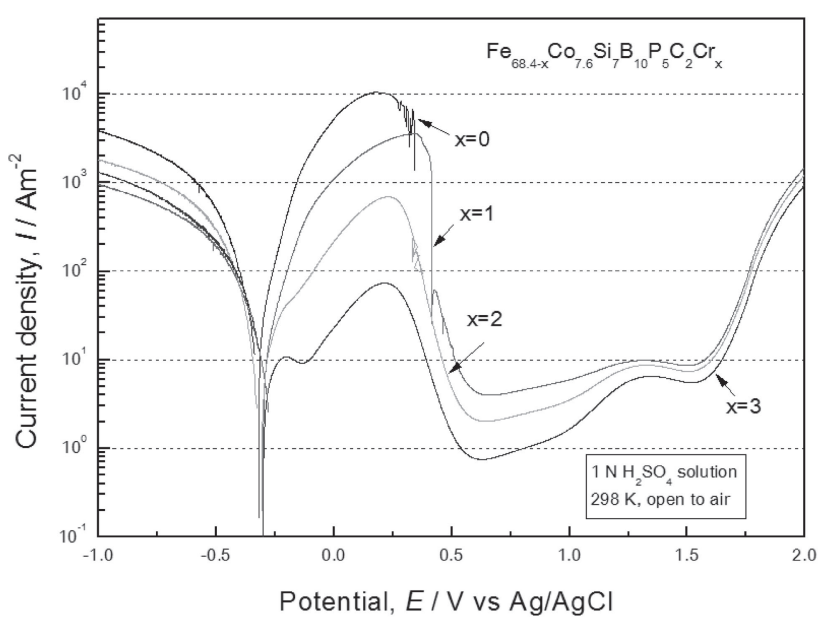

Fig. 6 Potentiodynamic polarization curves of $\mathrm{Fe}_{68.4-x} \mathrm{Co}_{7.6} \mathrm{Si}_{7} \mathrm{~B}_{10} \mathrm{P}_{5} \mathrm{C}_{2} \mathrm{Cr}_{x}$ $(x=0 \sim 3)$ glassy alloy rods with a diameter of $2 \mathrm{~mm}$ in $0.5 \mathrm{~mol} / \mathrm{L} \mathrm{NaCl}$ solution open to air at $298 \mathrm{~K}$.

air at $298 \mathrm{~K}$. The $\mathrm{Fe}_{68.4} \mathrm{Co}_{7.6} \mathrm{Si}_{7} \mathrm{~B}_{10} \mathrm{P}_{5} \mathrm{C}_{2}$ alloy dissolves actively and its anodic current density increases quickly by anodic polarization. In addition, the stable polarization curve cannot be obtained, because the surface of the sample suffers a severe damage by the further anodic polarization. However, the addition of $\mathrm{Cr}$ element significantly improves the corrosion resistances of the FeCoSiBPC alloys. All the Crcontaining alloys exhibit a wide passivation region in $1 \mathrm{~N}$ $\mathrm{H}_{2} \mathrm{SO}_{4}$ solution and the glassy alloys containing different amount of $\mathrm{Cr}$ content show similar corrosion behavior in this solution. Hence, the corrosion resistance of Cr-containing glassy alloys is enhanced according to the formation of Cr-enriched surface film during immersion in $1 \mathrm{~N} \mathrm{H}_{2} \mathrm{SO}_{4}$ solution.

\section{Conclusion}

A new Fe-based BGA system was developed by microalloying $\mathrm{Cr}$ element to $\mathrm{Fe}_{68.4} \mathrm{Co}_{7.6} \mathrm{Si}_{7} \mathrm{~B}_{10} \mathrm{P}_{5} \mathrm{C}_{2}$ alloy. The addition of a small amount of $\mathrm{Cr}$ is found to be effective in enhancing the corrosion resistance and GFA of the bulk glassy alloys. When 2 at\% Cr element substitutes Fe element, the supercooled liquid region $\left(\Delta T_{x}\right)$ increases to $59 \mathrm{~K}$, the glass-forming ability is significantly enhanced and the critical diameter increases from $3.5 \mathrm{~mm}$ to $5.0 \mathrm{~mm}$. The glassy alloys exhibit high mechanical property, and the yield strengths are 3700-3800 MPa. The alloys also exhibit a rather high softmagnetic property. The saturation magnetization and coercive force is $1.21-1.35 \mathrm{~T}$ and $2.7-3.1 \mathrm{~A} / \mathrm{m}$, respectively. With the addition of $\mathrm{Cr}$ element, a Cr-enriched surface film can form on the surface, which can prevent further corrosion of internal material. The corrosion resistance of the Fe-based alloy can be significantly improved by adding a small amount of $\mathrm{Cr}$, which provides a new idea for the application of Fe-based BGAs.

\section{Acknowledgment}

This work was sponsored by the National Natural Science Foundation of China (Grant No. 51501084), Natural Science Foundation of Liaoning Province (Grant No. 201602398) and the Foundation of University of Science and Technology Liaoning (Grant No. 2015RC01).

\section{REFERENCES}

1) R.Z. Yang, Y.Z. He, H. Zhang and S.D. Huang: Ocean Eng. 147 (2018) 277-288.

2) K. Key: Surv. Geophys. 33 (2012) 135-167.

3) R. Winston Revie: Uhlig's Corrosion Handbook, 3rd Edition (John Wiley \& Sons, Inc., New Jersey, 2011) pp. 83-91.

4) S.J. Pang, T. Zhang, K. Asami and A. Inoue: Acta Mater. 50 (2002) 489-497.

5) S.J. Pang, T. Zhang, K. Asami and A. Inoue: J. Mater. Res. 17 (2002) 701-704.

6) P. Duwez and S.C.H. Lin: J. Appl. Phys. 38 (1967) 4096-4097.

7) A. Inoue and A. Takeuchi: Acta Mater. 59 (2011) 2243-2267.

8) A. Inoue, F.L. Kong, Q.K. Man, B.L. Shen, R.W. Li and F. AlMarzouki Man: J. Alloys Compd. 615 (2014) S2-S8.

9) A. Inoue: Engineering 1 (2015) 185-191.

10) J.F. Wang, W.B. Cao, L.G. Wang, S.J. Zhu, S.K. Guan, L. Huang, R. Li and T. Zhang: J. Alloys Compd. 637 (2015) 5-9.

11) A. Inoue and A. Takeuchi: Int. J. Glass Sci. 1 (2010) 273-295.

12) Z.L. Long, Y. Shao, G.Q. Xie, P. Zhang, B.L. Shen and A. Inoue: J. Alloys Compd. 462 (2008) 52-59.

13) M. Stoica, J. Eckert, S. Roth and L. Schultz: Mater. Sci. Eng. A 375377 (2004) 399-402.

14) X. Li, C.L. Qin, H. Kato, A. Makino and A. Inoue: J. Alloys Compd. 509 (2011) 7688-7691. 
15) M. Shi, Z.Q. Liu and T. Zhang: J. Magn Mater. 378 (2015) 417-423.

16) M. Shi, R. Li, J.F. Wang, Z.Q. Liu, X.K. Luo and T. Zhang: Philos. Mag. 93 (2013) 2182-2189.

17) M. Shi, Z.Q. Liu and T. Zhang: J. Mater. Sci. Technol. 31 (2015) 493 497.

18) X. Li, C.T. Chang, T. Kubota, C.L. Qin, A. Makino and A. Inoue: Mater. Trans. 49 (2008) 2887-2890.

19) X. Li, K. Yubuta, A. Makino and A. Inoue: Mater. Sci. Eng. A 527 (2010) 2598-2602.

20) H.Y. Jung and S. Yi: Intermetallics 18 (2010) 1936-1940.

21) S.L. Wang, H.X. Li, X.F. Zhang and S. Yi: Mater. Chem. Phys. 113
(2009) 878-883.

22) T. Xu, S. Pang and T. Zhang: J. Alloys Compd. 625 (2015) 318-322.

$23)$ C.A.C. Souza, D.V. Ribeiro and C.S. Kiminami: J. Non-Cryst. Solids 442 (2016) 56-66.

24) A. Makino, T. Kubota, C.T. Chang, M. Makabe and A. Inoue: Mater. Trans. 48 (2007) 3024-3027.

25) A.D. Wang, C.L. Zhao, H. Men, A.N. He, C.T. Chang, X.M. Wang and R.W. Li: J. Alloys Compd. 630 (2015) 209-213.

26) C.L. Zhao, A.D. Wang, A.N. He, S.Q. Yue, C.T. Chang, X.M. Wang and R.W. Li: J. Alloys Compd. 659 (2016) 193-197. 